\title{
Strategies for the evaluation of DNA damage and repair mechanisms in cancer (Review)
}

\author{
GABRIELA FIGUEROA-GONZÁLEZ ${ }^{1}$ and CARLOS PÉREZ-PLASENCIA ${ }^{1,2}$ \\ ${ }^{1}$ Genomics Laboratory, National Cancer Institute of Mexico, Mexico City 14080; ${ }^{2}$ Functional Genomics Laboratory, \\ FES-Iztacala, The Autonomous University of Mexico, Tlalnepantla, Estado de Mexico 54090, Mexico
}

Received October 27, 2016; Accepted January 6, 2017

DOI: $10.3892 / \mathrm{ol} .2017 .6002$

\begin{abstract}
DNA lesions and the repair mechanisms that maintain the integrity of genomic DNA are important in preventing carcinogenesis and its progression. Notably, mutations in DNA repair mechanisms are associated with cancer predisposition syndromes. Additionally, these mechanisms maintain the genomic integrity of cancer cells. The majority of therapies established to treat cancer are genotoxic agents that induce DNA damage, promoting cancer cells to undergo apoptotic death. Effective methods currently exist to evaluate the diverse effects of genotoxic agents and the underlying molecular mechanisms that repair DNA lesions. The current study provides an overview of a number of methods that are available for the detection, analysis and quantification of underlying DNA repair mechanisms.
\end{abstract}

\section{Contents}

1. Introduction

2. Molecular strategies

3. Fluorescence strategies

4. Chemiluminescence strategies

5. Analytical strategies

6. Conclusions

\section{Introduction}

There are numerous strategies with inherent advantages and disadvantages that may be used for the evaluation of DNA damage and repair. DNA is the primary target following exposure to stimuli such as ultraviolet (UV) radiation, DNA

Correspondenceto:DrCarlosPérez-Plasencia,FunctionalGenomics Laboratory, FES-Iztacala, The Autonomous University of Mexico, 1 De los Barrios Avenue, Tlalnepantla, Estado de Mexico 54090, Mexico

E-mail: carlos.pplas@gmail.com

Key words: DNA damage, DNA repair, double-strand break, single-strand break alkylators, certain environmental carcinogens, oxidative stress and chemotherapeutic drugs (1). All these damaging factors produce lesions on DNA and a base alteration promoting a break in the DNA helix (2). Double-strand breaks (DSBs) are lethal to cells, as they affect both strands of DNA and promote the loss of genetic information (3). DNA damage, which frequently occurs in eukaryotic cells, may promote genomic instability and aid the development of disease, including cancer (4). Following DNA damage, cellular responses are induced and allow the cell to repair the damage or process the damage via a variety of mechanisms (5). Therefore, DNA repair proteins are important biomarkers for predicting the response of tumors to genotoxic stress and the prognosis of patients with more accuracy. This highlights the importance of detecting and quantifying DNA damage. There are a number of strategies that allow the investigation of these underlying mechanisms and the current review discusses these strategies and highlights their importance. These techniques may be separated into two perspectives: Techniques for detecting DNA damage and techniques for evaluating the underlying repair mechanisms.

\section{Molecular strategies}

Polymerase chain reaction (PCR) and agarose gel electrophoresis. Breaks in DNA reduce the molecular weight of a single DNA strand, and this may be caused by physical, chemical or enzymatic reagents (6). DNA breaks and lesions may be detected by PCR or using agarose gel electrophoresis (7).

PCR is one of the most frequently used techniques for detecting DNA damage (7). DNA amplification is stopped at the sites of damage via the blocking of the progression of Taq polymerase, which results in a decrease in the quantity of PCR product and a reduced number of DNA templates, which do not contain the Taq-blocked lesions as they are not amplified (8). This is considered to be a simple and reliable method in which particular segments of DNA are specifically replicated and visualized using agarose gels that resolve a range of DNA fragments (50-50,000 bp) dependent on the agarose percentage (8).

Quantitative PCR (qPCR) has been performed to quantify the amount of DNA damage on both strands, as well as the kinetics of DNA damage removal in the mitochondrial DNA (mtDNA) of human and other organisms $(7,9)$. The technique has been used to measure the formation and repair of $\mathrm{UV}$-induced photoproducts in a $1.2-\mathrm{kb}$ fragment of the $\mathrm{LacI}$ 
gene from Escherichia coli (8) and to measure the damage to mtDNA in Schizosaccharomyces pombe cells treated with hydrogen peroxide (10). The frequency of cisplatin-induced lesions has been investigated in a series of fragments ranging from 150 to $2,000 \mathrm{bp}$ from the hamster aprt gene (11). Taken together, these previous studies have demonstrated the ability to detect and analyze gene-specific DNA damage and repair with PCR (12). The qPCR method is dependent on high-molecular weight DNA, DNA quantification, qPCR conditions, quantification of amplification products and the calculation of lesion frequencies (8), and has the advantage of quantitative detection of DNA damage in a specific gene that is expressed mathematically in terms of lesions per $\mathrm{kb}$ and the requirement of only 1-2 ng of total genomic DNA (9).

Ligation-mediated PCR (LMPCR) analyzes the distribution of the two types of UV-induced DNA photoproducts, namely cyclobutane pyrimidine dimers and 6-4 photoproducts. The technique has the capability to detect an individual DNA photoproduct at low UV doses $\left(10-20 \mathrm{~J} / \mathrm{m}^{2}\right)$ and is also highly sensitive for studying the interactions of proteins and DNA in vivo (13), and for measuring the repair of cyclobutane pyrimidine dimers (14). By contrast, terminal transferase-dependent PCR (TDPCR) is a technique that adds a terminal transferase prior to ligation to an oligonucleotide, and as with LMPCR, this method is able to map pyrimidine 6-4 pyrimidone photoproducts and obtain information on the in vivo chromatin structure (15).

Immuno-coupled PCR (ICPCR) combines nucleic acid amplification with an antibody-based assay in which the detection enzyme in the ELISA is replaced with a biotinylated reporter DNA bound to an antigen-antibody complex (16). This methodology allows for the quantification of thymine dimer formations in genes and these have been established to be directly proportional to the global levels identified in UV radiation-exposed human genomic DNA (17). PCR-based short interspersed DNA element (SINE)-mediated is also a highly sensitive assay that detects DNA adducts produced by drug treatment, including cisplatin (18) or UV-B induced damage, and detects repair in the mammalian genome (19). This assay relies on the abundance, dispersion and conservation of the SINEs in mammalian genomes (19). Compared with conventional PCR and qPCR, this method differs in that it involves the amplification of long segments of DNA in the transcribed regions of the genome in a faster and more cost-effective manner (18).

\section{DNA repair proteins that are used as molecular markers}

Ku protein. $\mathrm{Ku}$ is a heterodimer consisting of two subunits (70 and $80 \mathrm{kDa}$ ) that bind to a $470-\mathrm{kDa}$ catalytic subunit termed the DNA-dependent protein kinase, which is involved in repairing DNA DSBs (20). The DSB repair pathway is dependent on $\mathrm{Ku}$ protein and is the primary DNA DSB repair mechanism in mammalian cells (21). The ability of $\mathrm{Ku}$ to function affects numerous nuclear processes besides DNA repair, including telomere maintenance and apoptosis (22). $\mathrm{Ku}$ protein has also been implicated in cell survival, which suggests that the detection of $\mathrm{Ku}$ protein expression may be used as a strategy for evaluating DNA damage and repair (22). The majority of previous studies have focused on the function of $\mathrm{Ku}$ in DNA DSB repair via the non-homologous end joining pathway, and cells or animals deficient in this protein are defective in DSB rejoining and are hypersensitive to ionizing radiation (23). For the expression and purification of full-length $\mathrm{Ku}$ heterodimer, it is necessary to have co-expression of $\mathrm{Ku} 70$ and $\mathrm{Ku} 80$, and subsequently, the protein must be separated and purified via chromatographic techniques (24).

Phosphorylated histone $2 A X(\gamma H 2 A X)$ protein. $\mathrm{H} 2 \mathrm{AX}$ is a member of the histone $\mathrm{H} 2 \mathrm{~A}$ family and it has been established that elevated phosphorylation levels of $\mathrm{H} 2 \mathrm{AX}$ on genomic DNA damage occur within 1-3 min of DNA damage (25). The detection of $\gamma \mathrm{H} 2 \mathrm{AX}$ protein phosphorylated at Serine-139 allows an approach for detecting and quantifying DNA DSBs, as the number of Serine-139- $\gamma \mathrm{H} 2 \mathrm{AX}$ molecules is associated with the quantity of DNA damage (26), therefore it may be used as a marker of DSBs. The primary method for detecting $\gamma \mathrm{H} 2 \mathrm{AX}$ is based on immunofluorescence using a specific antibody for Serine-139- $\gamma \mathrm{H} 2 \mathrm{AX}$ to demonstrate its localization in chromatin foci at the sites of DNA damage (25). Indirect identification has been used via flow cytometry (FCM) using secondary antibodies tagged with fluorescein isothiocyanate (FITC), while DNA has been counterstained with propidium iodide (PI) to analyze an association between the presence of DSBs and cell cycle phase (27).

$X$-ray repair cross complementing 1 (XRCC1) protein. The $\mathrm{XRCC} 1$ protein serves an important role in promoting efficient repair of DNA single-strand breaks (SSBs) in mammalian cells (28). XRCC1 is able to interact with multiple enzymatic components that are involved in the repair process, including DNA ligase IIIa, DNA polymerase $\beta$, apurinic/apyrimidinic endonuclease 1, polynucleotide kinase/phosphatase, poly(ADP-ribose) polymerase 1 and 2, and 8-oxoguanine DNA glycosylase $(29,30)$. Previous studies have established that certain polymorphisms in the XRCC1 gene are associated with cancer risk (31). The regulation of XRCC1 protein levels in human cell lines has been investigated using RNA interference and demonstrated that the reduction of XRCC1 affects the repair pathways of SSBs, as well as having an important role in DNA base excision repair (BER) $(30,32)$. These events may be evaluated using the comet assay or using fluorescent or analytical techniques that are described in this review. For example, DNA repair assays to evaluate the possible role of XRCC1 in the rejoining of chromosomal SSBs are performed using alkaline elution, alkaline unwinding, or comet assay, meanwhile, for evaluating the role of XRCC1 in the rejoining of DSBs, neutral $\mathrm{pH}$ elution from a DNA filter has been employed (33).

\section{Fluorescence strategies}

Comet assay. The comet assay, also known as single-cell gel electrophoresis, is simple and is considered to be one of the gold standard methods for measuring DNA strand breaks (single or double) in eukaryotic cells $(34,35)$. In addition to being a method for detecting DNA breaks, it is also possible to detect UV-induced pyrimidine dimers, oxidized bases and alkylation damage following the introduction of lesion-specific endonucleases (36).

This technique identifies the head of the comet as a spherical mass of undamaged DNA, and the damaged DNA (DNA loops around strand breaks) streams out from the head as a tail $(37,38)$. The comet structure was first described in a study by Ostling and 
Johanson (39), which explained the tail in terms of DNA with relaxed supercoiling. In the most frequently performed type of comet assay, cells are embedded in agarose to immobilize the DNA and a lysis process is performed using a detergent and high salt. The comet assay has a limited resolution of $10-800 \mathrm{~kb}$ using standard conditions (40). Other variants of the comet assay are also used to assess DNA damage and its detection.

Alkaline single-cell gel electrophoresis. This version of the comet assay uses alkaline denaturation surrounding a DNA break to reveal the break (single or double) (41). This method enhances comet tails and extends the range of DNA damage that is detected, but sensitivity has not been increased compared to the use of lesion-specific enzymes (34).

Neutral single-cell gel electrophoresis. This is a variant of the comet assay that uses an alkaline treatment, after which the conditions are restored to neutral, followed by gel electrophoresis in neutral or mild alkaline conditions (42). This method is less sensitive but remains able to detect SSBs (43).

Use of lesion-specific enzymes. The use of lesion-specific enzymes may aid in the detection of other types of DNA damage, other than SSBs or DSBs, including oxidized bases or pyrimidine dimers (44). The enzymes create an apurinic/apyrimidic site by removing the damaged base; endonucleases specifically detect oxidized pyrimidines, and formamidopyrimidine DNA glycosylases detect 8-oxo-7,8-dihydroguanine and ring opened-purines (35).

Bromodeoxyuridine-labelled DNA-comet fluorescence in situ hybridization (FISH). This technique combines a comet assay and FISH, and is effective in detecting damage and repair site-specific breaks in DNA regions in individual cells (40). This assay may be used to measure and discriminate between SSBs or DSBs or modifications from DNA repair.

Halo assay. This technique is based on the intercalation of PI into the DNA helix, which causes the DNA to become a supercoiled structure (45). Following lysis, the nucleoids of individual cells appear as 'halos' that correspond to DNA loops, which may be measured to determine the chromatin fragility. The 'halo' diameter is proportional with PI concentration and is expressed as relaxed or rewound supercoils at low PI and high PI, respectively (45). This method may aid the study of the effects of induced DNA damage, although it only detects alterations in the organization of DNA if the damage has not been repaired, which occurs at radiation doses of $2 \mathrm{~Gy}$. This assay has limitations on its sensitivity, but the advantages are that it is able to measure the DNA damage of a single cell and no labeling of DNA with radioactive precursors is required (46).

Terminal deoxynucleotidyl transferase (TdT) dUTP nick-end labeling (TUNEL) assay. The TUNEL assay detects SSBs or DSBs, as well as levels of apoptosis via the visualization of DNA fragmentation (45). This assay primarily uses the ability of the enzyme TdT to incorporate nucleotide analogues conjugated with a fluorochrome onto the free $3^{\prime}-\mathrm{OH}$ of a DNA strand, therefore allowing the visualization of the nuclei that contain fragmented DNA (47). Additionally, fluorescence may be detected using a fluorescent dye conjugated antibody that recognizes biotin- or digoxigenin-tagged nucleotides (48). As the assay is able to detect the DNA fragments with fluorescence or radioactivity, microscopy techniques, FCM, photo-multipliers and charge coupled device arrays may be used to detect and quantify DNA damage caused by apoptosis (49). Typically, the visualization of DNA damage is possible as the morphological alterations occur in the nucleus, including alterations in structural organization and the collapse of chromatin (49). During the degradation of DNA, a specific pattern of fragments is generated by the activity of endonucleases enzymes, and fragmentation of genomic DNA occurs into lower molecular weight fragments from DNA (47).

Although this method was designed for detecting DNA damage following apoptosis, DNA fragments with 3'-OH ends may occur in a number of other situations where apoptosis does not take place, including necrosis (49). The TUNEL assay is limited in its sensitivity and specificity, but it may also be used to stain cells undergoing DNA repair (50). TUNEL is not considered sufficient to establish the type of cell death and must be accompanied by another method that allows for the distinction of the origin of the DNA fragmentation in cells undergoing apoptosis or non-apoptotic DNA damage (51). One of the assays that is considered to specifically detect DNA DSBs and used in combination with TUNEL assay is the in situ ligation assay (52), which is based on ligation of double-stranded oligonucleotide probes by T4 DNA ligase to the ends of the DNA breaks directly in tissue sections (53).

DNA breakage detection (DBD)-FISH. FISH is a technique for the visualization of nucleic acids that improves resolution, speed and safety compared with older methods that use isotopic detection $(54,55)$. This technology also allowed for the development of simultaneous detection of multiple targets, quantitative analyses and live-cell imaging (54). FISH is typically used to locate and examine chromosomal, genetic and genomic aberrations that are associated with the development and progression of disease (56). Therefore, it has clinically important applications in cytogenetic and oncology, including in identifying gene alterations in patients with cancer (56). A modification of this technique, DBD-FISH, has been used to investigate cervical cancer progression by detecting and quantifying DNA breaks in genomic regions that are sensitive to destabilization (57). This technique allows detection and quantification of SSBs and DSBs in the genome or in a specific DNA sequence from a single cell (58). There are certain disadvantages in fluorescence assays, including the reproducibility and irregularity of the signals, and background autofluorescence (54).

FCM-Annexin V labeling. When DNA breakage occurs, it is important to differentiate between necrosis, autolysis and apoptosis (59). FCM was developed to detect apoptosis (60); this method allows for the measure of a large number of cells, and is also used to detect DNA strand fragmentation, chromosomal aberrations and chemical adducts in DNA $(61,62)$.

Annexin $\mathrm{V}$ protein is used to quantify the number of dead or apoptotic cells (63). The lipid bilayer in healthy cells does not allow for Annexin $\mathrm{V}$ binding, however, in cells undergoing apoptosis, Annexin V binds to the outer surface of the cell membrane following translocation of phosphatidylserine in the presence of $\mathrm{Ca}^{2+}$ (64). The number of apoptotic cells may be 
quantified using FCM (65). With the use of a secondary antibody tagged with FITC or PI, this method may detect important proteins involved in DNA repair complexes (27). FCM is able to rapidly and sensitively measure DNA damage compared with the frequently used comet assay method.

Radioimmunoassay (RIA). The RIA binding assay is used to measure the concentration of antigens using specific antibodies. The target antigen is synthesized with a radiolabel and without a label, and is subsequently bound to specific antibodies (66). Following the introduction of a sample, a competitive reaction develops between the radiolabeled antigens and the unlabeled antigens from the sample, and this releases an amount of radiolabeled antigen. Standard curves may be obtained from this process by mixing equal amounts of antibody and radiolabeled antigen, with increasing concentrations of non-labeled antigen in a constant volume; unknown antigen is similarly mixed with antibody and radiolabeled antigen, and the concentration may be subsequently determined (67). This assay may be used to estimate the quantity of 6-4 photoproducts and cyclobutane dimers in DNA (45).

\section{Chemiluminescence strategies}

Enzyme-linked immunosorbent assay (ELISA). This is one of the most commonly used immunological methods for the quantification of DNA damage (67) and consists of affixing an unknown quantity of antigen to a surface and applying an unknown quantity of antibody to the surface so that the antibody binds to the antigen. The antibody is linked to an enzyme that may be quantified via the addition of an appropriate substrate (colored, fluorescent or radioactive) $(45,67)$.

Immunohistochemical assay. This assay utilizes fixed cells that have previously been treated with proteases and RNase. This process removes proteins and RNA, and this ensures that cross-reaction with DNA does not occur (67). A solution of PI is used to counterstain the cells. The resulting immunofluorescence allows for visualization of the nuclei in adduct-negative cells (45). Immunohistochemical assays, in addition to FISH, have served as a more effective screening and diagnostic tool to detect alterations in certain metabolites, including the case of ALK gene in non-small cell lung cancer (68).

Immunological assay. This technique measures the presence of oxidative DNA via the immunoslot-blot system, and uses chemiluminescent detection and secondary antibodies that are conjugated to alkaline phosphatase enzymes and radioactive iodine (69). This assay is effective, but is limited by the cross-reactivity of the antibodies with normal DNA bases.

\section{Analytical strategies}

High performance liquid chromatography (HPLC)-electrospray tandem mass spectrometry (MS). Oxidative stress and absorption of UV light by nucleic acids has been established to be one of the causes of oxidative DNA damage, which may promote cancer development $(70,71)$. The improvement of HPLC coupled to tandem MS with an electrospray ionization mode, may be a sensitive and accurate method to detect modified bases of the oxidative-damaged DNA and UV-induced dimeric pyrimidine photoproducts (72). Notably, during the initial steps of the BER, the simultaneous detection and quantification of altered and released nucleobases from genomic DNA may be conducted using HPLC-MS (73). Therefore, this technique may be useful for detecting SSBs, as these lesions and base alterations are involved with proteins of the BER pathway (74).

This assay has been used to quantify oxidized nucleosides, including 8-oxo-7,8-dihydro-2'-deoxyguanosine, 8-oxo-7,8-dihydro-2'-deoxyadenosine, 5-formyl-2'-deoxyuridine, 5-hydroxymethyl-2'-deoxyuridine, 5-hydroxy-2'-deoxyuridine and the four diastereomers of 5,6-dihydroxy-5,6-dihydrothymidine within isolated and cellular DNA following exposure to $\gamma$-rays (75). It is also possible to detect tandem DNA lesions as dinucleoside monophosphates, and in addition to detecting the type of DNA damage, HPLC-MS may also provide information on the location and quantity of DNA damage $(75,76)$. Despite the advantage of accuracy, this assay has the limitations of a high cost and the large amount of experience that is required to accurately use the technique to monitor the formation of low levels of oxidized bases within cellular DNA (75). However, it remains the method of choice for measuring modified DNA bases.

Gas chromatography-mass spectrometry (GC-MS). To understand diverse cellular processes, including DNA damage, repair and its biological consequences, it is important to characterize and quantify DNA lesions.

MS provides structural evidence for a biological or chemical analysis, and in combination with gas chromatography, it enables measurements of more complex samples (77). GC-MS is a technique capable of measuring numerous products of DNA damage, including those of the sugar moiety and heterocyclic bases, as in HPLC-MS (78). The MS analysis provides sensitive detection of a single DNA lesion in DNA with multiple lesions or nucleobases following chemical or enzyme degradation of the nucleic acids (79). Additionally, this technique measures the kinetics of a number of DNA repair enzymes and is able to identify and quantify the expression levels of DNA repair proteins in human tissues $(80,81)$. Typically, these measurements include the hydrolysis of DNA, the derivatization of hydrolysates and the separation via gas chromatography of hydrolysates that are identified and quantified using MS (78). GC-MS has also been used to identify DNA-protein crosslinks, including Thy-Gly, Thy-Ala and Cyt-Tyr, in mammalian chromatin in vitro (82-84).

Electrochemical methods (EM). It has been established that DNA may be damaged by reactive oxygen species and the alterations in DNA that are formed are detected using electrochemical methods based on the inherent sensitivity of DNA-mediated charge transport (CT). These methods are also capable of detecting base pair mismatches and the majority of base damage products (85). This methodology may detect DNA-mediated CT as a damage detection mechanism for DNA repair enzymes (86). There have been hypotheses regarding the development of a sensor for the detection of single base mutations and DNA base lesions in duplex DNA to utilize the sensitivity of this charge to transport DNA films (87). The electrochemical method, electrocatalysis, has provided the basis for novel assays to detect low levels of lesions and possible for use as an early diagnostic tool. Although this is a method that provides sensitive, selective and 


\section{lonizing Radiation, ROS, Alkylating agents, Genotoxic agents, Replication errors, UV, DNA lesions unrepaired}

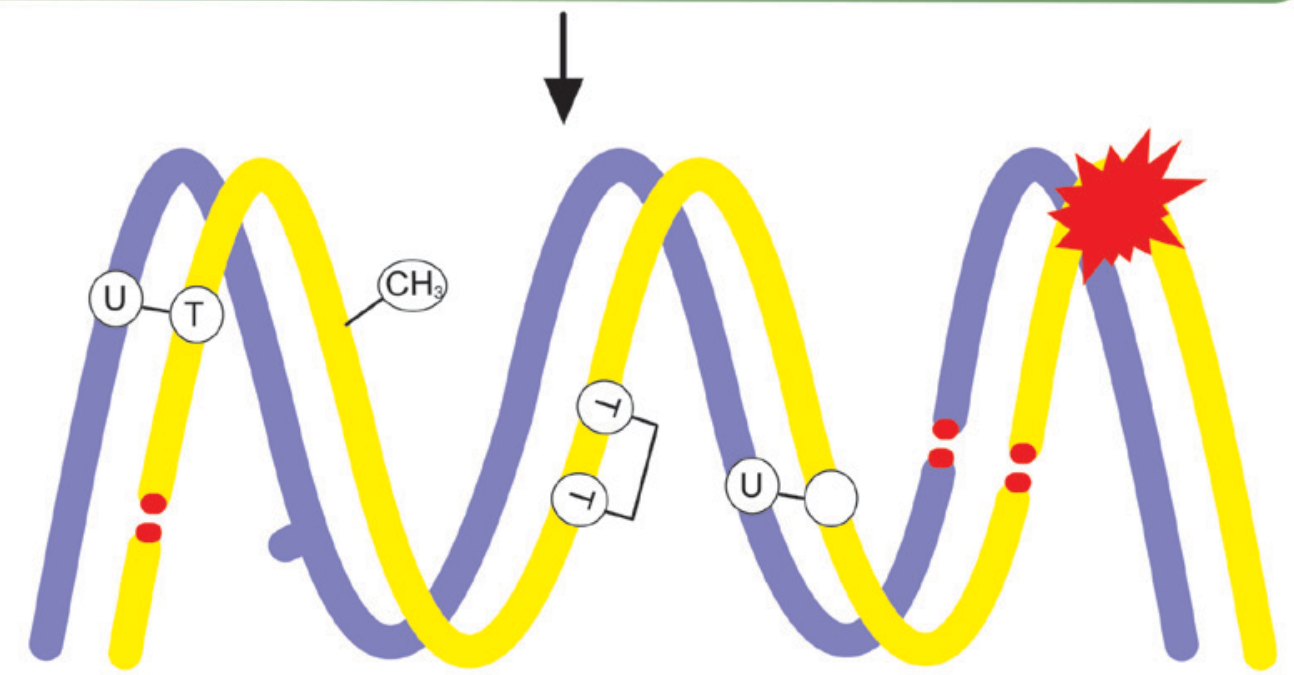

\begin{tabular}{|c|c|c|c|c|c|c|}
\hline$\sum_{0} \frac{\overline{0}}{0}$ & $\begin{array}{l}\text { Single-strand } \\
\text { break } \\
\text { Altered base }\end{array}$ & $\begin{array}{c}0^{6} \text { alkyl } \\
\text { guanine } \\
\text { Bulky adduct }\end{array}$ & $\begin{array}{l}\text { Pyrimidine dimers } \\
\text { 6,4-photoproduct }\end{array}$ & Deletion & $\begin{array}{l}\text { Double strand } \\
\text { break }\end{array}$ & $\begin{array}{l}\text { Stalled } \\
\text { replication fork }\end{array}$ \\
\hline 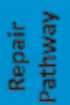 & BER & NER & DRR & MMR & $\begin{array}{l}\text { NHEJ } \\
\text { HR } \\
\text { SSA }\end{array}$ & $\begin{array}{l}\text { TLS } \\
\text { BIR }\end{array}$ \\
\hline 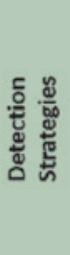 & $\begin{array}{c}\text { COMET } \\
\text { HALO } \\
\text { TUNEL } \\
\text { HPLC-MS } \\
\text { DBD-FISH } \\
\text { GC-MS } \\
\text { Protein XRCC1 } \\
\text { EM }\end{array}$ & $\begin{array}{c}\text { HPLC-MS } \\
\text { GC-MS } \\
\text { IHC }\end{array}$ & $\begin{array}{l}\text { TDPCR } \\
\text { LMPCR } \\
\text { ICPCR } \\
\text { HPLC-MS } \\
\text { GC-MS } \\
\text { RIA } \\
\text { ELISA } \\
\text { EM }\end{array}$ & GC-MS & $\begin{array}{c}\text { COMET } \\
\text { TUNEL } \\
\text { LAM-HTGTS } \\
\text { DBD-FISH } \\
\text { Protein Ku } \\
\text { Protein } \gamma H 2 A X\end{array}$ & PCR \\
\hline
\end{tabular}

Figure 1. Summary of distinct types of DNA lesions, the repair pathways involved in their repair and the experimental strategies that are used to evaluate each type. ROS, reactive oxygen species; UV, ultraviolet; BER, base excision repair; NER, nucleotide excision repair; DDR, DNA damage repair; MMR, mismatch repair; NHEJ, non-homologous end joining; HR, homologous recombination; SSR, single strand repair; TLS, translesion synthesis; BIR, base incision repair; COMET, single-cell gel electrophoresis; TUNEL, terminal deoxynucleotidyl transferase dUTP nick-end labeling; HPLC-MS, high performance liquid chromatography-mass spectrometry; DBD-FISH, DNA breakage detection-fluorescence in situ hybridization; GC-MS, gas chromatography-mass spectrometry; XRCC1, X-ray repair cross complementing 1; EM, electrochemical methods; IHC, immunohistochemistry; TDPCR, terminal transferase-dependent polymerase chain reaction; LMPCR, ligation-mediated polymerase chain reaction; ICPCR, immune-coupled polymerase chain reaction; RIA, radioimmunoassay; ELISA, enzyme-linked immunosorbent assay; LAM-HTGTS, linear amplification-mediated high-throughout genome-wide translocation sequencing; PCR, polymerase chain reaction.

low cost detection of DNA damage, it has the limitation of not being able to recognize thymidine dimer lesions until they are connected with the distortion of DNA double helix (45).

\section{Conclusions}

Fig. 1 presents a summary of the distinct types of DNA lesions, the repair pathways that are involved and the experimental strategies used to evaluate each type. The importance of the study of DNA damages and how damage may be restored requires further study, as it has clinical implications in multifactorial diseases, including cancer and diabetes. There are a number of methods available for the detection, analysis and quantification of DNA lesions and it is important to identify the advantages and disadvantages of each approach. The combination of these methodologies may provide an overview of DNA lesion analysis and complementary information. In contrast to the methodologies described in the present review, these molecular strategies may be considered to be accurate and sensitive, as they examine the type of DNA damage as well as the repair mechanism involved. Notably, the accumulated research in the current review may promote further studies to demonstrate potential phenotypic alterations that occur from DNA lesions. 


\section{Acknowledgements}

This review was supported by CONACyT research funds (grant no. PN-2014-249020) and the National Autonomous University of México (grant no. PAPIIT-IN207216).

\section{References}

1. Cadet J and Wagner JR: DNA base damage by reactive oxygen species, oxidizing agents, and UV radiation. Cold Spring Harb Perspect Biol 5: a012559, 2013.

2. Li Z, Pearlman AH and Hsieh P: DNA mismatch repair and the DNA damage response. DNA Repair (Amst) 38: 94-101, 2016.

3. Altaf M, Saksouk N and Côté J: Histone modifications in response to DNA damage. Mutat Res 618: 81-90, 2007.

4. Lord CJ and Ashworth A: The DNA damage response and cancer therapy. Nature 481: 287-294, 2012.

5. Cao LL, Shen C and Zhu WG: Histone modifications in DNA damage response. Sci China Life Sci 59: 257-270, 2016.

6. Schipler A and Iliakis G: DNA double-strand-break complexity levels and their possible contributions to the probability for error-prone processing and repair pathway choice. Nucleic Acids Res 41: 7589-7605, 2013.

7. Grimaldi KA, McGurk CJ, McHugh PJ and Hartley JA: PCR-based methods for detecting DNA damage and its repair at the sub-gene and single nucleotide levels in cells. Mol Biotechnol 20: 181-196, 2002.

8. Osborne DJ: Technologies for detection of DNA damage and mutations. Endeavour 21: 178-179, 1997.

9. Furda A, Santos JH, Meyer JN and van Houten B: Quantitative PCR-based measurement of nuclear and mitochondrial DNA damage and repair in mammalian cells. In: Molecular Toxicology Protocols. Keohavong P and Grant GS (eds.) Humana Press, Totowa, NJ, pp419-437, 2014.

10. Senoo T, Yamanaka M, Nakamura A, Terashita T, Kawano S and Ikeda S: Quantitative PCR for detection of DNA damage in mitochondrial DNA of the fission yeast Schizosaccharomyces pombe. J Microbiol Methods 127: 77-81, 2016.

11. De Boer JG and Glickman BW: Mutations recovered in the Chinese hamster aprt gene after exposure to carboplatin: A comparison with cisplatin. Carcinogenesis 13: 15-17, 1992.

12. Van Houten B, Cheng S and Chen Y: Measuring gene-specific nucleotide excision repair in human cells using quantitative amplification of long targets from nanogram quantities of DNA Mutat Res 460: 81-94, 2000.

13. Strauss EC and Orkin SH: Guanine-adenine ligation-mediated PCR in vivo footprinting. Methods 11: 164-170, 1997.

14. Pfeifer GP and Tornaletti S: Footprinting with UV irradiation and LMPCR. Methods 11: 189-196, 1997.

15. Pfeifer GP, Chen HH,Komura J and Riggs AD: Chromatin structure analysis by ligation-mediated and terminal transferase-mediated polymerase chain reaction. Methods Enzymol 304: 548-571, 1999.

16. Chang L, Li J and Wang L: Immuno-PCR: An ultrasensitive immunoassay for biomolecular detection. Anal Chim Acta 910: 12-24, 2016.

17. Karakoula A, Evans MD, Podmore ID, Hutchinson PE, Lunec J and Cooke MS: Quantification of UVR-induced DNA damage: Global-versus gene-specific levels of thymine dimers. J Immunol Methods 277: 27-37, 2003.

18. Wang G, Hallberg LM and Englander EW: Rapid SINE-mediated detection of cisplatin: DNA adduct formation in vitro and in vivo in blood. Mutat Res 434: 67-74, 1999.

19. Wang G, Hallberg LM, Saphier E and Englander EW: Short interspersed DNA element-mediated detection of UVB-induced DNA damage and repair in the mouse genome, in vitro, and in vivo in skin. Mutat Res 433: 147-157, 1999.

20. Featherstone $\mathrm{C}$ and Jackson SP: Ku, a DNA repair protein with multiple cellular functions? Mutat Res 434: 3-15, 1999.

21. Jones JM, Gellert M and Yang W: A Ku bridge over broken DNA. Structure 9: 881-884, 2001.

22. Gullo C, Au M, Feng G and Teoh G: The biology of Ku and its potential oncogenic role in cancer. Biochim Biophys Acta 1765: 223-234, 2006

23. Doherty AJ and Jackson SP: DNA repair: How Ku makes ends meet. Curr Biol 11: R920-R924, 2001.
24. Walker JR, Corpina RA and Goldberg J: Structure of the $\mathrm{Ku}$ heterodimer bound to DNA and its implications for double-strand break repair. Nature 412: 607-614, 2001

25. Paull TT, Rogakou EP, Yamazaki V, Kirchgessner CU, Gellert M and Bonner WM: A critical role for histone H2AX in recruitment of repair factors to nuclear foci after DNA damage. Curr Biol 10: 886-895, 2000.

26. Rogakou EP, Boon C, Redon C and Bonner WM: Megabase chromatin domains involved in DNA double-strand breaks in vivo. J Cell Biol 146: 905-916, 1999.

27. Henderson DS (ed): DNA repair protocols. In: Methods in Molecular Biology. 2nd edition. Humana Press, New Jersey, NJ, p498, 2006

28. Levy N, Martz A, Bresson A, Spenlehauer C, De Murcia G and Ménissier-De Murcia J: Xrcc1 is phosphorylated by DNA-dependent protein kinase in response to DNA damage. Nucleic Acids Res 34: 32-41, 2006.

29. Caldecott KW: Protein-protein interactions during mammalian DNA single-strand break repair. Biochem Soc Trans 31: 247-251, 2003.

30. Brem R and Hall J: XRCC1 is required for DNA single-strand break repair in human cells. Nucleic Acids Res 33: 2512-2520, 2005.

31. Goode EL, Ulrich CM and Potter JD: Polymorphisms in DNA repair genes and associations with cancer risk. Cancer Epidemiol Biomarkers Prev 11: 1513-1530, 2002.

32. Strom CE, Mortusewicz O, Finch D, Parsons JL, Lagerqvist A, Johansson F, Schultz N, Erixon K, Dianov GL and Helleday T: CK2 phosphorylation of XRCC1 facilitates dissociation from DNA and single-strand break formation during base excision repair. DNA Repair (Amst) 10: 961-969, 2011.

33. Caldecott KW: XRCC1 and DNA strand break repair. DNA Repair (Amst) 2: 955-969, 2003.

34. Collins AR: The comet assay for DNA damage and repair: Principles, applications, and limitations. Mol Biotechnol 26: 249-261, 2004.

35. Collins AR: Measuring oxidative damage to DNA and its repair with the comet assay. Biochim Biophys Acta 1840: 794-800, 2014

36. Collins AR and Azqueta A: DNA repair as a biomarker in human biomonitoring studies; further applications of the comet assay. Mutat Res 736: 122-129, 2012.

37. Kent CR, Eady JJ, Ross GM and Steel GG: The comet moment as a measure of DNA damage in the comet assay. Int J Radiat Biol 67: 655-660, 1995

38. Jyoti S, Khan S, Naz F, Rahul, Ali F and Siddique YH: Assessment of DNA damage by panmasala, gutkha chewing and smoking in buccal epithelial cells using alkaline single cell gel electrophoresis (SCGE). Egyptian J Med Human Gen 14: 391-394, 2013.

39. Ostling O and Johanson KJ: Microelectrophoretic study of radiation-induced DNA damages in individual mammalian cells. Biochem Biophys Res Commun 123: 291-298, 1984.

40. Glei M, Hovhannisyan G and Pool-Zobel BL: Use of comet-FISH in the study of DNA damage and repair: Review. Mutat Res 681: 33-43, 2009.

41. Collins AR, Dobson VL, Dušinská M, Kennedy G and Štětina R: The comet assay: What can it really tell us? Mutat Res 375: 183-193, 1997.

42. Rojas E, Lopez MC and Valverde M: Single cell gel electrophoresis assay: Methodology and applications. J Chromatogr B Biomed Sci Appl 722: 225-254, 1999.

43. Angelis KJ, Dusinská M and Collins AR: Single cell gel electrophoresis: Detection of DNA damage at different levels of sensitivity. Electrophoresis 20: 2133-2138, 1999.

44. Collins AR and Azqueta A: Chapter 4-single-cell gel electrophoresis combined with lesion-specific enzymes to measure oxidative damage to DNA. In: Methods in Cell Biology. Conn PM (ed.) Academic Press, Burlington, MA, pp69-92, 2012.

45. Kumari S, Rastogi R, Singh K, Singh S and Sinha R: DNA damage: Detection strategies. EXCLI J 7: 44-62, 2008.

46. Roti Roti JL and Wright WD: Visualization of DNA loops in nucleoids from HeLa cells: Assays for DNA damage and repair. Cytometry 8: 461-467, 1987.

47. Gavrieli Y, Sherman Y and Ben-Sasson SA: Identification of programmed cell death in situ via specific labeling of nuclear DNA fragmentation. J Cell Biol 119: 493-501, 1992.

48. Walker PR, Carson C, Leblanc J and Sikorska M: Labeling DNA damage with terminal transferase, in in situ detection of DNA damage. In: Methods and Protocols. Didenko VV (ed.) Humana Press, Totowa, NJ, pp3-19, 2002. 
49. Loo DT: TUNEL assay. An overview of techniques. Methods Mol Biol 203: 21-30, 2002.

50. Kanoh M, Takemura G, Misao J, Hayakawa Y, Aoyama T, Nishigaki K, Noda T, Fujiwara T, Fukuda K, Minatoguchi S and Fujiwara H: Significance of myocytes with positive DNA in situ nick end-labeling (TUNEL) in hearts with dilated cardiomyopathy: Not apoptosis but DNA repair. Circulation 99: 2757-2764, 1999.

51. Otsuki $Y$ and Ito Y: Quantitative differentiation of both free $3^{\prime}$ oh and 5' oh DNA ends using terminal transferase-based labeling combined with transmission electron microscopy, in in situ detection of DNA damage. In: Methods and Protocols. Didenko VV (ed.) Humana Press, Totowa, NJ, pp41-54, 2002.

52. Didenko VV and Hornsby PJ: Presence of double-strand breaks with single-base 3 ' overhangs in cells undergoing apoptosis but not necrosis. J Cell Biol 135: 1369-1376, 1996.

53. Didenko VV: Detection of specific double-strand DNA breaks and apoptosis in situ using T4 DNA ligase. Methods Mol Biol 203: 143-151, 2002.

54. Levsky JM and Singer RH: Fluorescence in situ hybridization: Past, present and future. J Cell Sci 116: 2833-2838, 2003.

55. Gall JG and Pardue ML: Formation and detection of RNA-DNA hybrid molecules in cytological preparations. Proc Natl Acad Sci USA 63: 378-383, 1969.

56. Halling KC and Kipp BR: Fluorescence in situ hybridization in diagnostic cytology. Hum Pathol 38: 1137-1144, 2007.

57. Cortés-Gutiérrez EI, Fernández JL, Dávila-Rodríguez MI, López-Fernández C and Gosálvez J: Use of DBD-FISH for the study of cervical cancer progression, in cervical cancer. In: Methods and Protocols. Keppler D and Lin WA (eds.) Springer, New York, NY, pp291-301, 2015.

58. Fernández JL, Vázquez-Gundín F, Rivero MT, Genescá A, Gosálvez J and Goyanes V: DBD-fish on neutral comets: SimuItaneous analysis of DNA single- and double-strand breaks in individual cells. Exp Cell Res 270: 102-109, 2001.

59. Fink SL and Cookson BT: Apoptosis, pyroptosis, and necrosis: Mechanistic description of dead and dying eukaryotic cells. Infect Immun 73: 1907-1916, 2005.

60. Basiji D and O'Gorman MR: Imaging flow cytometry. J Immunol Methods 423: 1-2, 2015

61. Muehlbauer PA and Schuler MJ: Detection of numerical chromosomal aberrations by flow cytometry: A novel process for identifying aneugenic agents. Mutat Res 585: 156-169, 2005.

62. Henry CM, Hollville E and Martin SJ: Measuring apoptosis by microscopy and flow cytometry. Methods 61: 90-97, 2013.

63. Huerta S, Goulet EJ, Huerta-Yepez S and Livingston EH: Screening and detection of apoptosis. J Surg Res 139: 143-156, 2007.

64. Vermes I, Haanen C, Steffens-Nakken $\mathrm{H}$ and Reutelingsperger C: A novel assay for apoptosis. Flow cytometric detection of phosphatidylserine expression on early apoptotic cells using fluorescein labelled Annexin V. J Immunol Methods 184: 39-51, 1995

65. Pietkiewicz S, Schmidt JH and Lavrik IN: Quantification of apoptosis and necroptosis at the single cell level by a combination of imaging flow cytometry with classical Annexin V/propidium iodide staining. J Immunol Methods 423: 99-103, 2015.

66. Berton TR and Mitchell DL: Quantification of DNA photoproducts in mammalian cell DNA using radioimmunoassay. Methods Mol Biol 920: 177-187, 2012.

67. Santella RM: Immunological methods for detection of carcinogen-DNA damage in humans. Cancer Epidemiol Biomarkers Prev 8: 733-739, 1999.
68. Yatabe Y: ALK FISH and IHC: You cannot have one without the other. J Thorac Oncol 10: 548-550, 2015.

69. Kriste AG, Martincigh BS and Salter LF: A sensitive immunoassay technique for thymine dimer quantitation in UV-irradiated DNA. J Photochem Photobiol A: Chemistry 93: 185-192, 1996.

70. El-Yazbi AF and Loppnow GR: Detecting UV-induced nucleic-acid damage. TrAC Trends Analytical Chemistry 61: 83-91, 2014.

71. Toyokuni S: Oxidative stress as an iceberg in carcinogenesis and cancer biology. Arch Biochem Biophys 595: 46-49, 2016.

72. Rindgen D, Turesky RJ and Vouros P: Determination of in vitro formed DNA adducts of 2-amino-1-methyl-6-phenylimidazo [4,5-b]pyridine using capillary liquid chromatography/electrospray ionization/tandem mass spectrometry. Chem Res Toxicol 8: 1005-1013, 1995

73. Mullins EA, Rubinson EH, Pereira KN, Calcutt MW, Christov PP and Eichman BF: An HPLC-tandem mass spectrometry method for simultaneous detection of alkylated base excision repair products. Methods 64: 59-66, 2013.

74. Caldecott KW: DNA single-strand break repair. Exp Cell Res 329: 2-8, 2014.

75. Cadet J, Douki T, Frelon S, Sauvaigo S, Pouget JP and Ravanat JL: Assessment of oxidative base damage to isolated and cellular DNA by HPLC-MS/MS measurement. Free Radic Biol Med 33: 441-449, 2002

76. Pouget JP, Douki T, Richard MJ and Cadet J: DNA damage induced in cells by gamma and UVA radiation as measured by HPLC/ GC-MS and HPLC-EC and comet assay. Chem Res Toxicol 13: 541-549, 2000.

77. Gowda GA and Djukovic D: Overview of mass spectrometry-based metabolomics: Opportunities and challenges. Methods Mol Biol 1198: 3-12, 2014.

78. Dizdaroglu M, Coskun E and Jaruga P: Measurement of oxidatively induced DNA damage and its repair, by mass spectrometric techniques. Free Radic Res 49: 525-548, 2015.

79. Sato K and Greenberg MM: Selective detection of 2-deoxyribonolactone in DNA. J Am Chem Soc 127: 2806-2807, 2005.

80. Dizdaroglu M: Substrate specificities and excision kinetics of DNA glycosylases involved in base-excision repair of oxidative DNA damage. Mutat Res 531: 109-126, 2003.

81. Reddy PT, Jaruga P, Nelson BC, Lowenthal M and Dizdaroglu M: Stable isotope-labeling of DNA repair proteins and their purification, and characterization. Protein Expr Purif 78: 94-101, 2011.

82. Gajewski E and Dizdaroglu M: Hydroxyl radical induced cross-linking of cytosine and tyrosine in nucleohistone. Biochemistry 29: 977-980, 1990.

83. Koivisto P and Peltonen K: Analytical methods in DNA and protein adduct analysis. Anal Bioanal Chem 398: 2563-2572, 2010.

84. Dizdaroglu M and Gajewski E: Structure and mechanism of hydroxyl radical-induced formation of a DNA-protein cross-link involving thymine and lysine in nucleohistone. Cancer Res 49: 3463-3467, 1989.

85. Fojta M, Daňhel A,Havran L and Vyskočil V: Recent progress in electrochemical sensors and assays for DNA damage and repair. TrAC Trends Analytical Chemistry 79: 160-167, 2016.

86. Boal AK and Barton JK: Electrochemical detection of lesions in DNA. Bioconjug Chem 16: 312-321, 2005.

87. Boon EM, Ceres DM, Drummond TG, Hill MG and Barton JK: Mutation detection by electrocatalysis at DNA-modified electrodes. Nat Biotechnol 18: 1096-1100, 2000. 